\title{
Floral morphology and anatomy of Dalechampia alata Klotzsch ex Baill. (Euphorbiaceae), with emphasis on secretory structures
}

\author{
F. M. Martins ${ }^{a}$, I. L. Cunha-Neto ${ }^{a *}$ and T. M. Pereira ${ }^{b}$ \\ ${ }^{a}$ Laboratório de Anatomia Vegetal, Centro de Ciências Agrárias, Ambientais e Biológicas, Universidade Federal \\ do Recôncavo da Bahia - UFRB, Rua Rui Barbosa, 710, CEP 44380-000, Cruz das Almas, BA, Brazil \\ bUniversidade Estadual de Santa Cruz - UESC, Campus Soane Nazaré de Andrade, \\ Rodovia Jorge Amado, Km 16, Bairro Salobrinho, CEP 45662-900, Ilhéus, BA, Brazil \\ *e-mail: israellopescn@gmail.com
}

Received: September 25, 2014 - Accepted: November 26, 2014 - Distributed: February 29, 2016

(With 5 figures)

\begin{abstract}
The morphology and anatomy of the flower of Dalechampia alata, as well as the chemical nature of the exudates secreted in the inflorescence were studied using light microscope. This is the first report showing the presence of colleters in the genus Dalechampia. In the staminate flower occur a group of small secretory glands. The histochemical results indicate that the substance secreted from the glands is lipidic and resinuous in nature, while in the colleters it consists of polysaccharides and lipid-rich substances. The ovule of D. alata are anatropous, subglobose and bitegmic. It presents obturator, micropyle occluded by nucellar beak and meristematic activity in the ovary wall. The secretion produced in the stigmatic and transmitting tissue consists of polysaccharides.
\end{abstract}

Keywords: colleter, gland, histochemistry, meristematic activity, resin.

\section{Morfologia e anatomia da flor de Dalechampia alata Klotzsch ex Baill. (Euphorbiaceae), com ênfase nas estruturas secretoras}

\begin{abstract}
Resumo
A morfologia e anatomia das flores de Dalechampia alata, bem como a natureza química dos exsudatos secretados na inflorescência foram analisadas utilizando microscopia de luz. Este é o primeiro relato de coléteres para o gênero Dalechampia. Um grupo de pequenas glândulas secretoras ocorre nas flores estaminadas. Os resultados dos testes histoquímicos indicam que a substância secretada pelas glândulas apresenta natureza lipídica e resinosa, enquanto nos coléteres a secreção é constituída de polissacarídeos e lipídeos. O ovulo de $D$. alata é anátropo, subgloboso e bitegumentado. A presença de obturador, projeção do tecido nucelar pela micrópila e atividade meristemática na parede do ovário foram relatadas. A secreção do estigma e do tecido transmissor é constituída de polissacarídeos.
\end{abstract}

Palavras-chave: coléter, glândula, histoquímica, atividade meristemática, resina.

\section{Introduction}

The Euphorbiaceae exhibits a widespread distribution and is comprised of about 222 genera and 6100 species, but it is most diverse in tropical regions (Judd et al., 2009). The family is represented by about 80 genera and 1000 species in Brazil, making it one of the most important families of the country (Barroso et al., 1991). Taxonomically, the Euphorbiaceae is also one of the most complicated families of the Brazilian flora (Barroso et al., 1991).

A diversity of secretory structures is involved in the production of different compounds from secondary metabolism, documented in a number of Euphorbiaceae species (Metcalfe and Chalk 1950). The following types of secretory structures have already been recorded in the family: trichomes, idioblasts, laticifers, coletters, nectaries,

secretory cells with resinous contents, tannin cells, and mucilage lacunae (Solereder 1908; Metcalfe and Chalk 1950; Thomas 1991).

Dalechampia Plum ex. L., subfamily Acalyphoideae and tribe Plukenetieae, is the only genus of the subtribe Dalechampiinae (Tokuoka and Tobe, 2003) comprising approximately 120 species of lianas or rarely shrubs that are distributed throughout of the lowland tropics of the world (Armbruster et al., 2009). Armbruster (1996) calculated that approximately 90 species occur in the Neotropics, mostly in South America (Armbruster and Webster, 1981).

Dalechampia bears self-compatible, unisexual flowers clustered into open and bisexual, blossom inflorescences (pseudanthia). Most accounts of Dalechampia flowers 
anatomy are based on a study of $D$. scandens L. and D. stipulacea Müll.Arg. which were studied by Webster and Webster (1972) and Souza et al. (2010), respectively. Both species have bitegmic and anatropous ovule, obturator, trichomes and a resinuous gland, which is composed of flange-like structures that are modified bractlets (Webster and Webster, 1972). Tokuoka and Tobe (2003) studied ovules and seeds of Dalechampia caperonioides Baill., Dalechampia scandens L. and Dalechampia tiliifolia Lam., observing that besides the presence of bitegmic ovules, all species are characterized by the absence of vascular bundle in the inner integument.

Several studies about the pollination ecology of Dalechampia have been published over the years observing that in most species of this genus, flowers secrete a triterpene resin from specialized glands to attract pollinators (Armbruster, 1984). As noted by Armbruster (1996), this resin is commonly collected by bees for use in nest construction. Later studies have suggested that the resin-reward system seen in Dalechampia vines evolved by exaptation, whereby resin secretion originated as a defense mechanism and secondarily provided an attractive function (Armbruster et al., 2009).

Although there are many studies about pollination ecology, only a few studies have focused on the anatomy and morphology of Dalechampia flowers. While it is well known that the substance secreted from Dalechampia flowers is of resinous nature, no previous histochemical studies have been published to support these studies or to evaluate the composition of the exudate in other structures in the inflorescence.

The goal of this study is to describe the morphology and anatomy of the flower of Dalechampia alata Klotzsch ex Baill., as well as the chemical nature of the exudates secreted in the inflorescence.

\section{Material and Methods}

Samples of adult individuals of Dalechampia alata Klotzsch ex Baill. growing in Cruz das Almas in the state of Bahia, Brazil (12 $2^{\circ} 40^{\prime} 19^{\prime}$ S, 39 06' 22” W) were colletcted, herborized, and deposited in the HERB (Herbarium of the Universidade Federal do Recôncavo da Bahia) Brazil, Bahia: Cruz das Almas, HERB 4107.

Whole buds (5-10 mm long) and flowers of $D$. alata were collected at four stages, during bud development, anthesis and flowering. The material was fixed in 50\% FAA (37\% formaldehyde, glacial acetic acid, 50\% ethanol) for 24 hours (Johansen, 1940) and neutral-buffered formaldehyde solution (FNT) for 48 hours (Lillie, 1965). All of the material was exposed to vacuum desiccation during the fixation process and then transferred to $70 \%$ ethyl alcohol. Samples were isolated and kept in $70 \%$ tertiary butyl alcohol for approximately seven days, dehydrated in a butilic alcohol series, and subsequently embedded in histological paraffin (Histosec/Merck, Johansen, 1940). Serial transversal and longitudinal sections (ca. 10-14 $\mu \mathrm{m}$ ) were made using a rotary microtome (Leica RM2245). The sections were stained with $1.5 \%$ alcoholic Safranin O and 1\% aqueous Astra Blue (Gerlach, 1969) and mounted on permanent slides with synthetic resin (Permount/Fisher).

Histochemical tests of the glands, colleters and transmitting tissue were performed on serial sections of floral buds that were fixed in FAA to test for polysaccharides, proteins, and water-soluble phenolic compounds, and in FNT to identify total lipids and lipid-soluble phenolic compounds. The controls for the lipophilic substances test included an extraction solution composed of chloroform/methanol/water/ $\mathrm{HCl}$ (66:33:4:1 v/v; High 1984). The treatments utilized are described in Table 1. Histochemical tests were also performed with sections taken from fresh samples using a cryomicrotome (Model CM1850; Leica Microsystems).

Photomicrographs were taken using an Olympus BX51 microscope equipped with an Olympus A330 digital camera. The photomicrographs were edited using Adobe Photoshop 9.0 software. The figure scales were obtained by photographing a millimeter scale under the same optical conditions.

\section{Results}

\subsection{Inflorescence and flower morphology}

Dalechampia alata possesses a pseudanthium inflorescence with bilateral symmetry. The staminate flowers and pistillate cymes are protected by two yellow-greenish bracts, which are involucral, and foliaceous with serrate margins and five-lobed apices (see Figure 1A). The bracts exhibit actinodromous venation with five veins diverging radially from a single point. Non-glandular and unicellular trichomes and colleters are present in the axils of the bracts. At the base of the inflorescence occur four entire stipules, which are pilose, lanceolate with entire margin.

The staminate inflorescence is a pleiochasium with 5-6 flowers (see Figure 1B-C) and four bracteoles. The flowers are pedicellate and monochlamydeous with six yellow-greenish tepals, an androphore and numerous stamens (see Figure 1D). There are glands on the abaxial 'or' adaxial side of the stamens that secrete a greenish, sticky substance (see Figure 1B).

The pistillate flowers are clustered in cyme-like inflorescences that consist of three flowers, three laciniate tepals and one short, lanceolate, pilose, yellow-greenish bracteole (see Figure 1E). These flowers are monochlamydeous with a tricarpellate, apocarpousgynoecium and a superior, trilocular ovary. The three styles are elongate and cylindrical with non-papillous, undivided stigmas.

\subsection{Inflorescence and flower anatomy}

The involucral bract and bracteoles of the staminate flower have a single-layered epidermis on both surfaces (see Figure 2A, B). The ordinary epidermal cells are small, rounded in shape, and possess thin walls. The mesophyll has uniform parenchyma constituted by isodiametric cells that are variable in size, with the formation of small intercellular spaces. Bracts and bracteoles have inconspicuous collateral 
vascular bundles distributed in a single series arranged in the middle of the mesophyll (see Figure 2B).

The tepals of the staminate flowers have a single-layered epidermis formed by thin cell walls and cells that vary in shape from rounded to rectangular. The mesophyll consists of 2-3 parenchymatic isodiametric cells that vary in size and delimit large intercellular spaces. Small collateral vascular bundles are present and sparsely distributed in the mesophyll.

The pseudanthium presents non-glandular (see Figure 2B) and glandular trichomes (see Figure 2C). The non-glandular trichomes were small single-celled, while the glandular

Table 1. List of the histochemical tests used to identify the principal metabolic compounds secreted by the secretory structures of Dalechampia alata Klotzsch ex Baill.

\begin{tabular}{ccc}
\hline & Metabolite & Reagent \\
\hline \multirow{2}{*}{ Lipids } & Total Lipid & $\begin{array}{c}\text { Sudan Black B (Pearse, 1985) } \\
\text { Sudan Red (Brundrett et al., 1991) }\end{array}$ \\
\cline { 2 - 3 } & Acid and neutral lipids & Nile blue (Cain, 1947) \\
\hline Terpenoids & Essential oils and oleoresins & Nadi reagent (David and Carde, 1964) \\
\hline \multirow{2}{*}{ Phenolic compounds } & Phenolic general & Ferric chloride (Johansen, 1940) \\
\cline { 2 - 3 } & Tanin & Potassium dichromate (Gabe, 1968) \\
\hline Alkaloids & & Chloridric vanillin (Mace et al., 1974) \\
\hline & & Draggendorf reagent (Furr and Mahlberg, 1981) \\
\hline Polyssaccharides & Dittmar reagent (Furr and Mahlberg, 1981) \\
\hline & Total polysaccharides & Elram (Furr and Mahlberg, 1981) \\
\hline Proteins & Wcid mucopolysaccharides & Lagner reagent (Furr and Mahlberg, 1981) \\
\hline & Total proteins & PAS (Mchansen, 1940) \\
\hline
\end{tabular}
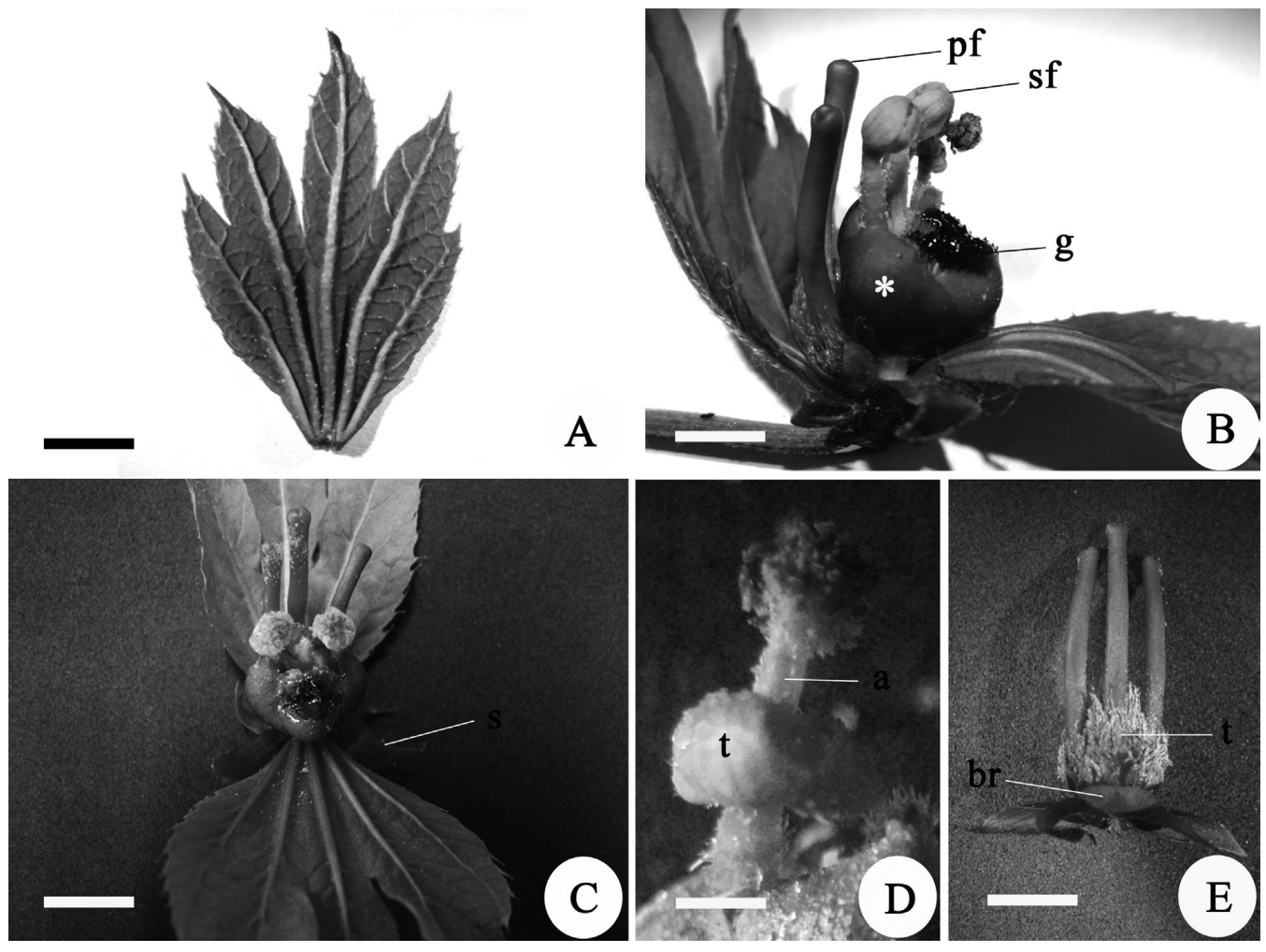

Figure 1. Inflorescence morphology of Dalechampia alata Klotzsch ex Baill. A. Bract. B. Inflorescence in lateral view. Note the completely developed glands. C. Inflorescence in upper 'or' top view. D. Staminate flower. Note the presence of the androphore. E. Carpellate flowers. (a - androphore; asterisk - bracteole of staminate flower; br - bracteole of pistillate flower; $\mathrm{g}$ - glands; pf - pistillate flower; $\mathrm{s}$ - stipule; $\mathrm{sf}$ - staminate flower; $\mathrm{t}$ - tepal). Bars: A-C = $2 \mathrm{~cm} ; \mathrm{D} ; \mathrm{E}=0,5 \mathrm{~cm}$. 

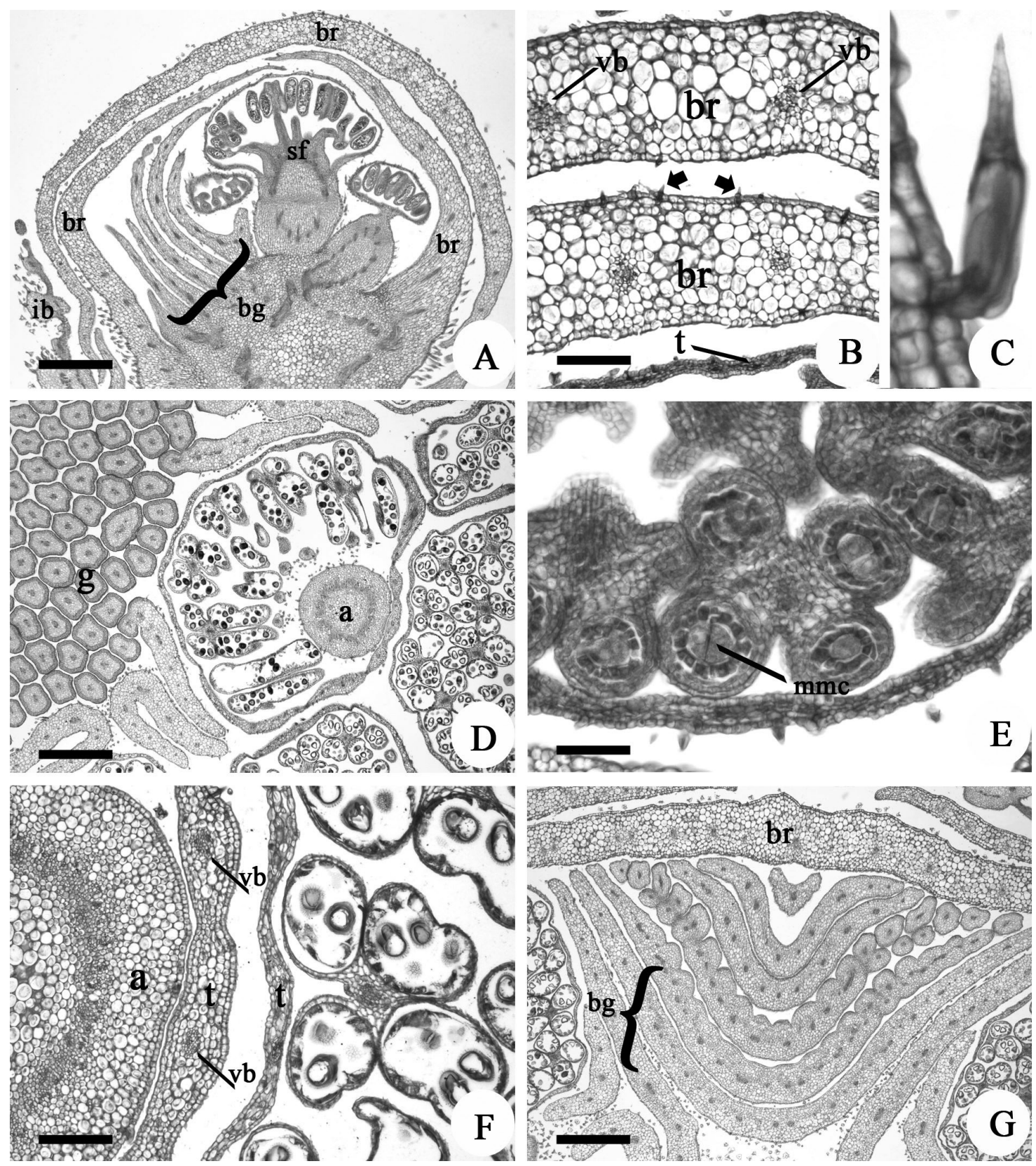

Figure 2. Staminate inflorescence anatomy of Dalechampia alata Klotzsch ex Baill.. A. Transversal section of the staminate flower showing the involucral bract, bracteoles, staminate flowers, and the glands in early stages of development. B. Transversal section of the bracteoles and tepal. Notice the inconspicuous vascular bundles and non-glandular trichomes (arrows) on the bracteoles. C. Detail of the pluricellular glandular trichomes (stinging hair). D. Staminate flower showing the androphore and the tetrasporangiate anthers. E. Transversal section of an anther at early microspore mother cell stage with epidermis, endothecium, middle layer, and tapetum. F. Detail of the androphore, tepals, and the anther. G. Blades on division for the formation of the staminate flower glands. ( $\mathrm{a}$ - androphore; arrow - trichomes; bg - blades of glands; br - bracteole; $\mathrm{g}$ - glands; ib - involucral bract; mmc - microspore mother cell; sf - staminate flower; $\mathrm{t}$ - tepal; vb - vascular bundle). Bars: A; $D ; G=4 \mu \mathrm{m} ; C ; E=80 \mu \mathrm{m} ; \mathrm{B} ; \mathrm{F}=40 \mu \mathrm{m}$.

trichomes were uniseriate and pluricellular. They were observed on the tepals, bracts, bracteoles and involucral bracts.

The androecium of $D$. alata is polystemonous (see Figure 2D). The anther is ovoid and tetrasporangiate with longitudinal dehiscence. Each stamen has four microsporangia arranged in two thecae. The young anther wall (see Figure 2E), when microspore mother cells are present, consists of a uniseriate epidermis, an endothecium formed by thin cell walls, one middle layer of cells similar 
to endothecium cells, and one layer of secretory tapetal cells. The mature anther wall consists of an epidermis with rectangular cells and an endothecium with thick-walled cells. The middle layer forms a discontinuous ring and the tapetal cells are absent due their disintegration in the previous stage. In the connective tissue the vascular bundle and undifferentiated parenchymatic cells were observed. The androphore has a single-layered epidermis with roughly square cells (see Figure 2F). The cortex consists of isodiametric parenchymatic cells that are variable in size. One cylinder formed by vascular bundles delimits a parenchymatic medulla.

Present in the staminate flowers on the abaxial 'or' adaxial side of the stamens is a group of small secretory glands (see Figures 2G, 3A). In these glands the secretory tissue consists of a uniseriate palisade epidermis with an acidophilous secretion on the cytoplasm (see Figure 3B). The palisade secretory epidermal cells are elongated and have thin walls covered by a cuticle. In cross section, the central region of the gland is occupied by parenchymatic cells forming very small intercellular spaces. Vascular tissue was also observed in the central region. When completely developed the glands form a structure that is approximately round in shape.
At first, gland formation takes place by successive divisions of 5-6 groups of laminas from the ground tissue (see Figure 2F). From the divisions of this tissue are formed dozens of individually units (see Figure $3 \mathrm{~A}$ ) that remain together until the end of the flower maturation when the secretion is released. Later all the tissue not integrated with the composition of the stamen also differentiates to form new glands. The gland secretion (see Figure 3B-F) is lipid and terpenoid in nature, as demonstrated by a positive reaction in tests with Sudan Black B (see Figure 3E), Nile Blue (see Figure 3F) and Nadi reagent (see Figure 3G) (see Table 2). The Sudan Red tests also highlighted the presence of cuticle covering all the secretory epidermal cells (see Figure 3D). Histochemical tests indicated that the cuticle does not rupture during secretion.

The bracteole of pistillate flowers has a single-layered epidermis (see Figure 4A, B). The ordinary epidermal cells are small and square or circular in shape. Stomata are absent. Mesophyll is homogeneous composed of parenchymatic isodiametric cells of varying sizes, forming small intercellular spaces. Vascularization is formed by collateral bundles immersed in the mesophyll (see Figure 4B).

In transverse section the ovary wall was observed to consist of an unistratified outer epidermis composed by
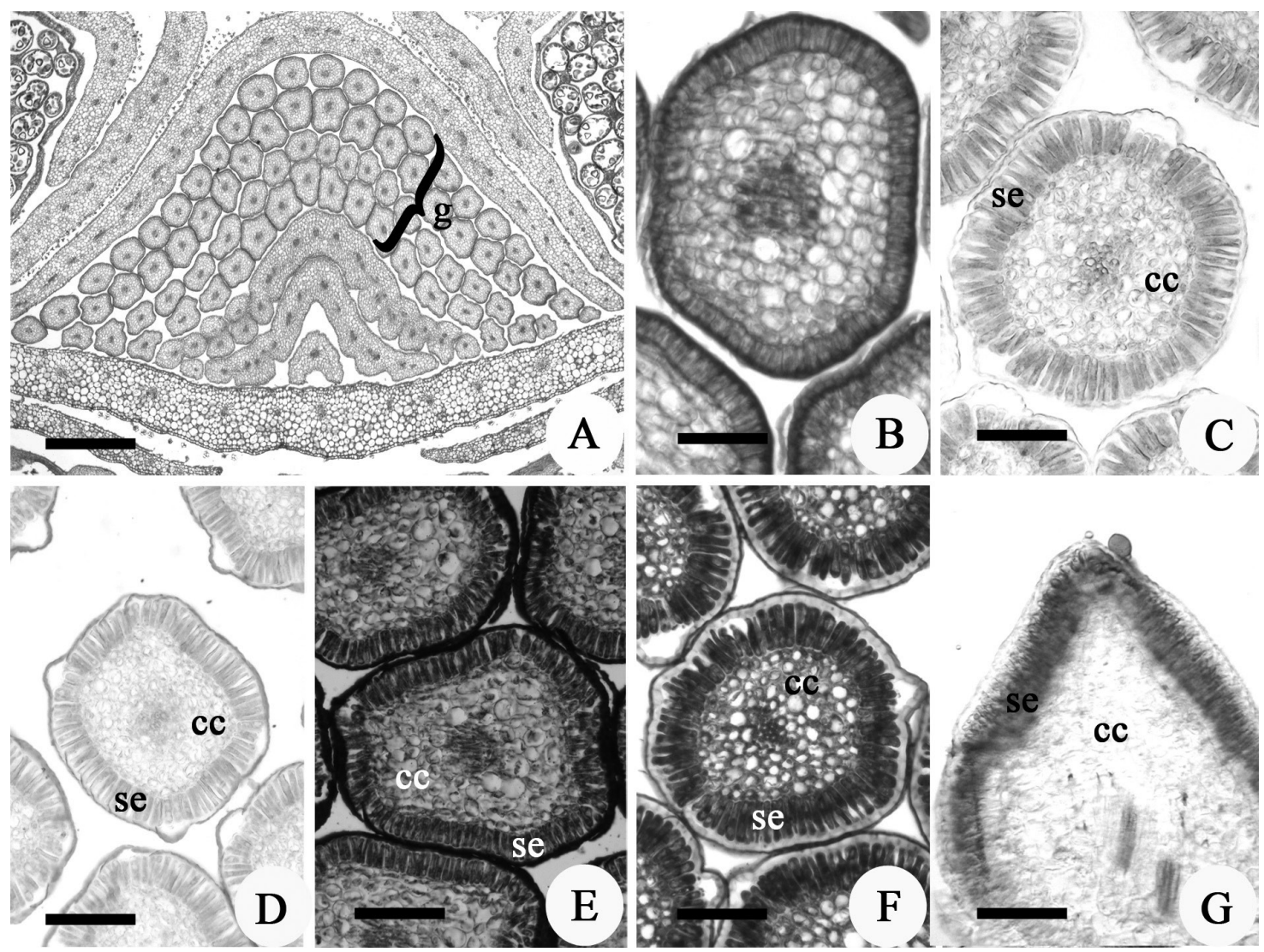

Figure 3. Structure and histochemistry of the staminate flower gland of Dalechampia alata Klotzsch ex Baill. in transversal sections. A. Glands of the staminates flowers. B. Detail of the gland structure. C. Glands not exposed to reagents. D. Sections stained with Sudan Red. E. Sections stained with Sudan Black B. F. Sections stained with Nile Blue. G. Sections stained with Nadi reagent. (g - glands; cc - central cells; se - secretory epidermis) Bars: A = $200 \mu \mathrm{m} ; \mathrm{B}=30 \mu \mathrm{m} ; \mathrm{C}-\mathrm{G}=50 \mu \mathrm{m}$. 
Table 2. Histochemical characterization of colleters, glands, and transmitting tissue from the inflorescence of Dalechampia alata Klotzsch ex Baill.

\begin{tabular}{cccccc}
\hline Metabolite & Reagent & Colleters & Glands & $\begin{array}{c}\text { Style Gland } \\
\text { (Souza et al., 2010) }\end{array}$ & $\begin{array}{c}\text { Transmitting } \\
\text { Tissue }\end{array}$ \\
\hline Lipids & Sudan Black B & + & + & - & - \\
& Sudan Scarlat & + & + & - & - \\
Nile Blue & + & + & - & - & - \\
Terpenoids & Nadi Reagent & - & + & - & - \\
Phenolic compounds & Ferric chloride & - & - & - & - \\
& Potassium dichromate & - & - & - & - \\
& Chloridric vanillin & - & - & - & - \\
Alkaloids & Dragendorf & - & - & - & - \\
& Dittmar reagent & - & - & - & - \\
Polysaccharides & Elram & - & - & - & - \\
Wagner reagent & Lugol & - & - & - & - \\
\hline
\end{tabular}

square cells containing dense cytoplasm (see Figure 4C). Mesophyll consists of multiple parenchymatous cell layers. Prior to anthesis, the inner epidermis and middle cell layers assume meristematic activity characterized by the occurrence of anticlinal and periclinal divisions. This results in the formation of two meristematic regions in the ovary wall, the adaxial meristem and the middle meristem. Between the two meristematic regions one can discern a layer of radially elongated rectangular cells that feature dense cytoplasm and conspicuous nucleus (see Figure 4C).

The seminal rudiments of $D$. alata are anatropous, subglobose, bitegmic, and crassinucellate, with a narrow conical nucellus (see Figure 4D, E). The micropyle is formed by the two integuments delimiting a narrow opening that is occluded by the nucellar beak (see Figure 4F). Occurring at the chalazal end of the ovule there is a cup-shaped region of thick-walled cells (see Figure 4G). These cells present cytoplasm that is intensely stained by safranin. Epidermal cells at the base of the funiculus are enlarged radially forming a projection with 5-6 layers of parenchyma cells (see Figure $4 \mathrm{H}$ ) which are not glandular in appearance. The integuments are multi-layered and covered by cuticle. The outer integument consists of 2-4 layers of isodiametric cells that are variable in size, while the inner integument is thicker with multiple layers of cells in the micropyle region. The vascular tissue occurs in the outer integument and extends from the chalaza to the inner integument (see Figure 4I). Stomata are present on the outer integument (see Figure 4J).

The style exhibits a single-layered epidermis (see Figure 4K, L) with unicellular non-glandular trichomes. In the middle third arises a sub-epidermal tissue formed by parenchymatic cells of varying shapes, compact arrangement, and of a significantly smaller size than the ordinary cells of the mesophyll (see Figure 4M, L).
Mesophyll is multiseriate with vascular bundles and transmitting tissue in the central region (see Figure 4M, P). The internal epidermal cells are round 'or' circular in shape and protect the stylar canal.

The enlarged stigma consists of a central triangular cavity that is contoured by non-papillose cells (see Figure 4N). Styles of D. alata have a mixed structure between the commonly encountered states of hollow or solid. The secretions present in the stigma and the central canal in the stigmatic and stylar transmitting tissue, took on a deep red coloration after staining with safranin, and they reacted strongly to PAS (see Figure 4O). Below the epidermal cells occur parenchymatic cells with reduced dimension and compact arrangement.

On the bracts of the pseudanthium (see Figure 5A) and on the axil of the stipules (see Figure 5B) colleters were found, presenting a wide variation in size and abundance. Generally, the colleters of D. alata feature a short stalk with a slightly sinuous outline, and they are identified as the standard type (see Figure 5C). Colleters with long stalks were also observed (see Figure 5D).

All of the colleter types were composed of a central nucleus of parenchyma cells covered by a uniseriate palisade secretory epidermis (see Figure 5C, D). The palisade secretory epidermal cells exhibit a thin cuticle and dense cytoplasm that stained strongly with safranin (see Figure 5C). Vascularization was only observed in the long-stalked colleters (see Figure 5D, E).

Histochemical tests (see Figure 5F-J) indicated that the cuticle becomes distended with the secretion apparently accumulating in this space between the external periclinal wall and the protoplast. Secretion was visible in the interior of the secretory epidermal cells and was stained with safranin. The results highlight the presence of mucilaginous substances in the vacuoles of 
the secretory cells as shown by a positive reaction to the PAS test (see Figure 5G). The presence of water and lipidsoluble substances were also identified by histochemical tests. Lipid substances were observed using Sudan Red (Figure 5H), Sudan Black B (see Figure 5I) and Nile Blue (see Figure 5J).
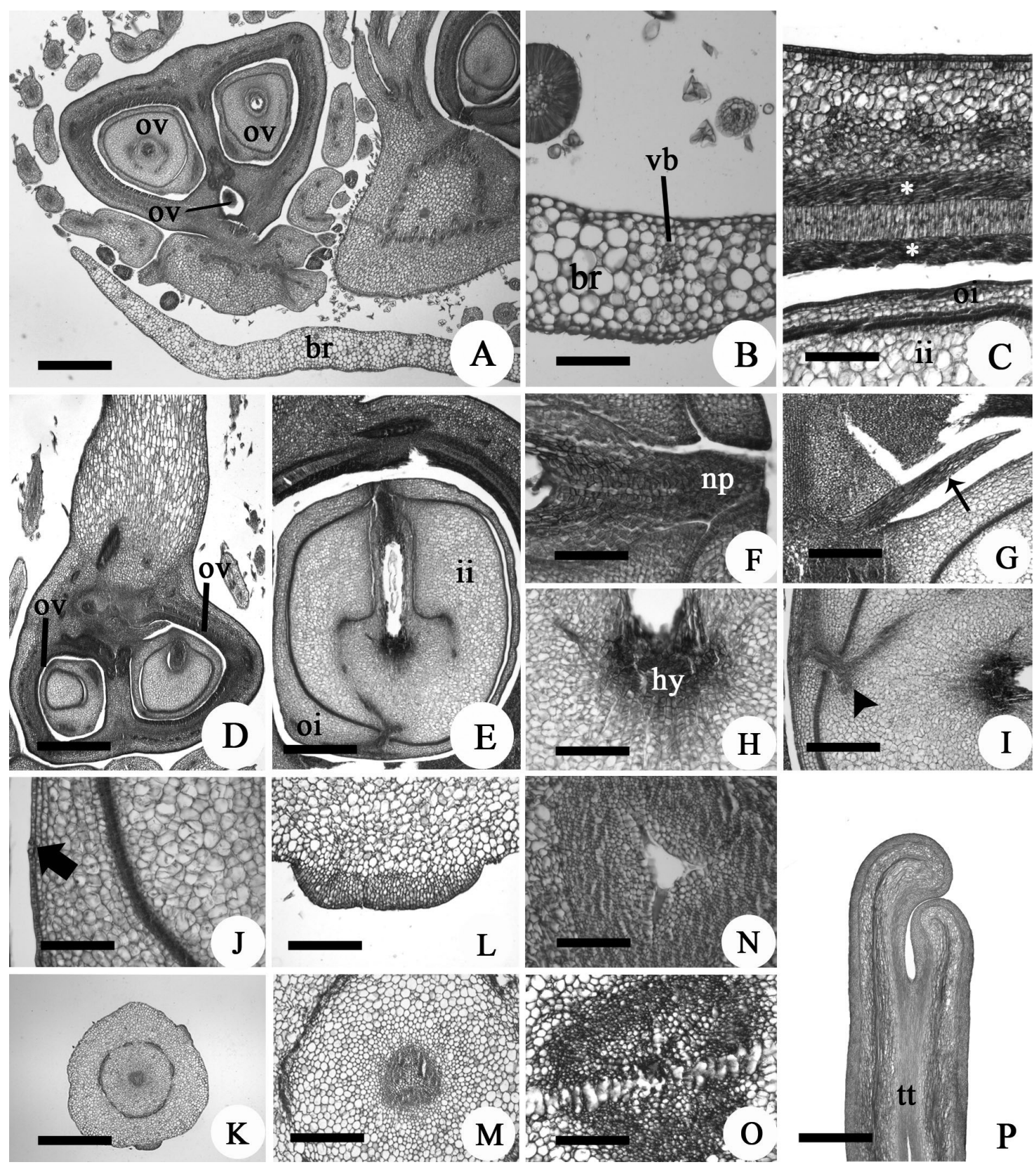

Figure 4. Ovary, seminal rudiment, stigma, and style structure of Dalechampia alata Klotzsch ex Baill.. A. Basal region of the pistilate flower in transversal section. Note the trilocular ovary. B. Bracteole detail. C. Ovary wall detail. D-J. Longitudinal sections. D. Ovary and style. E. Ovary and seminal rudiment. F. Micropyle detail. G. Obturator detail. H. Hypostase detail. I. Longitudinal section of the basal region of the ovary showing the vascular bundle. J. Stomata in the ovary wall. K-O. Transversal section of the style and stigma. K. Style. L. Detail of the differentiated subepidermal cells. M. Central region of the style. N. Stigmatic secretion stained with safranin. O. Positive reaction to PAS by the secretion from stigmatic and transmitting tissues. P. Longitudinal section of the style. (asterisk - meristematic region; br - bracteole; headarrow - vascular bundle; hy - hypostase; ii - inner integument; np - nucellus projection; oi - outer integument; ov - ovary; tt - transmitting tissue; thin arrow - obturator; thick arrow - stomata; vb - vascular bundle). Bars: A; K; P = 200 m; B; C; H; I; J; D; L; M; $\mathrm{N}=60 \mu \mathrm{m} ; \mathrm{E}=150 \mu \mathrm{m} ; \mathrm{F} ; \mathrm{G} ; \mathrm{J} ; \mathrm{O}=40 \mu \mathrm{m}$. 


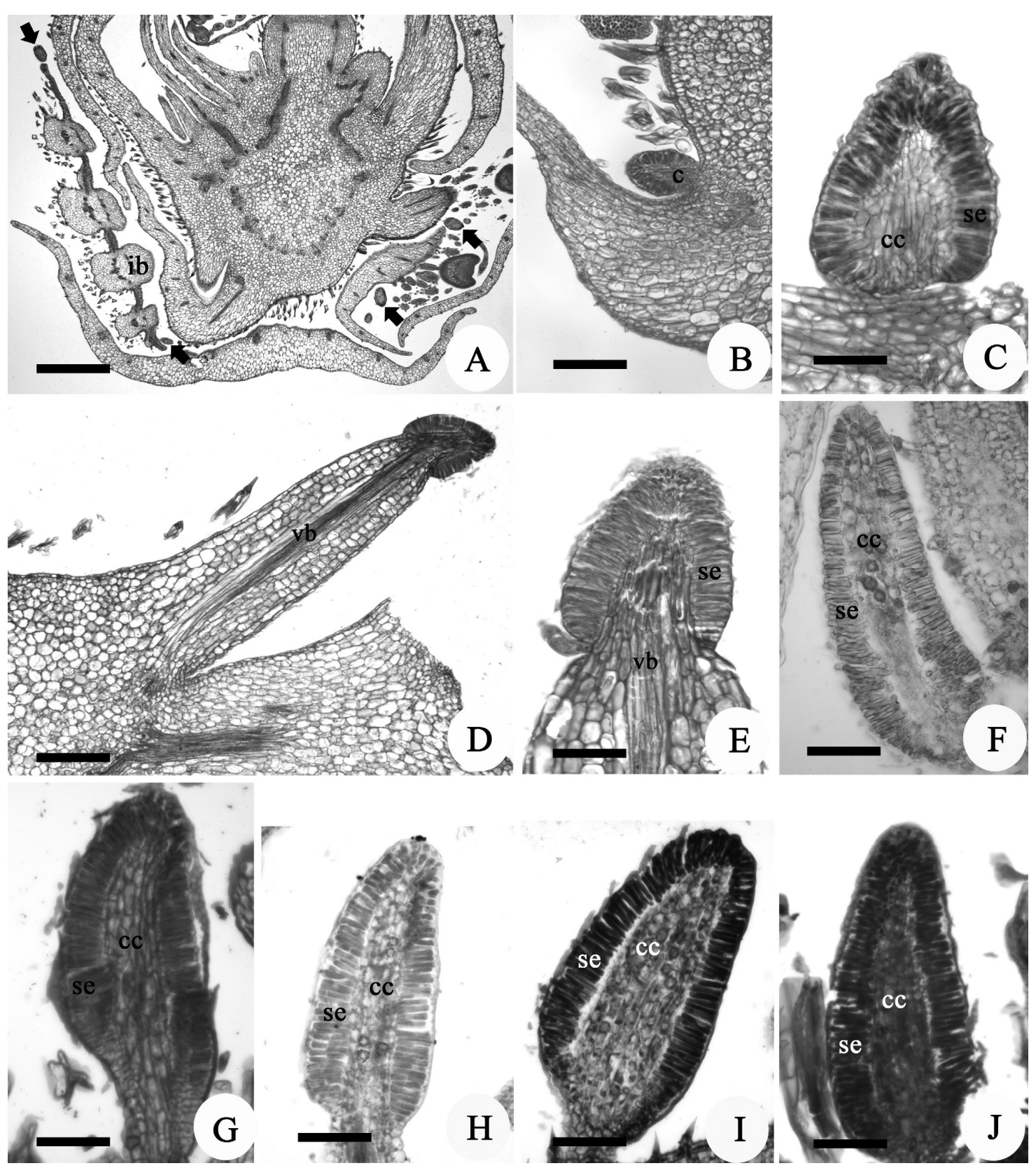

Figure 5. Structure and histochemistry of colleters on the pseudanthium of Dalechampia alata Klotzsch ex Baill. A. Transversal section of the pseudanthium. Notice the colleters (arrows) associated with the involucral bract and on the base of the pistillate flowers. B-J Longitudinal sections. B. Colleter found in the axile of the stipule. C. Detail of a standard colleter. D. Stalked colleter. E. Detail of the stalked colleter with conspicuous vascularization. Figure. F-J. Histochemical tests. F. Colleter not exposed to reagents. G. Colleter exposed to PAS reaction. H. Colleter stained with Sudan Red. I. Colleter stained with Sudan Black B. J. Colleter stained with Nile blue. (arrows - colleters; c - colleter; cc - central cells; ib - involucral bract; pf - pistillate flower; se - secretory epidermis; sf - staminate flower; vb - vascular bundle). Bars: A $=200 \mu \mathrm{m} ; \mathrm{B} ; \mathrm{D}=150 \mu \mathrm{m} ; \mathrm{C} ; \mathrm{E}-\mathrm{J}=40 \mu \mathrm{m}$.

\section{Discussion}

Morphological analysis of $D$. alata flowers showed that the organization of the flower verticels reflects the common features already described for the genus Dalechampia
(Webster and Webster, 1972; Souza et al., 2010). As seen in D. scandens (Webster and Webster, 1972) the glands in D. alata begins to secrete a yellow-greenish sticky material before the first male flowers open. Besides Dalechampia, the only other plants reported to secrete resins from floral 
structures belong to the genus Clusia L. and Clusiella Planch. \& Triana both Clusiaceae (Armbruster, 1984; Bittrich and Amaral, 1996).

Armbruster (1984) noted that the secretion of Dalechampia dissolves in ether, but not in water, confirming the resinous nature of the substance, which is probably a mixture of two to six oxygenated triterpenes. In the present study, histochemical tests confirmed that, in fact, the secreted substance from gland consists of terpenoids but also lipid, as shown by the positive reaction with Nadi reagent to detect terpenoids and Sudan Black B and Nile blue for lipids.

As described to other Dalechampia species, non-glandular and pluricellular glandular trichomes similar to stinging hairs were found in D. alata (Webster and Webster, 1972; Souza et al., 2010).

On the basis of the formation of the middle layers, Davis (1966) classified the development of anther walls into four types: basic, dicotyledonous, monocotyledonous, and reduced. As described for D. stipulacea (Souza et al., 2010) and other species of Euphorbiaceae (Liu et al., 2007; De-Paula and Sajo, 2011), D. alata might belong to the dicotyledonous type. However, a particular study regard anther wall formation in D. alata is required to give more details about this issue. In accordance with Liu et al. (2007), because of its variability, the type of anther wall development serves a limited purpose in the classification of the Euphorbiaceae.

Colleters have been described for approximately 60 families of Angiosperms and occur in just seven genera of Euphorbiaceae (Thomas, 1991), however, this is the first report showing the presence of colleters in the genus Dalechampia.

Colleters may be present on vegetative or reproductive organs, releasing a viscous fluid (mucilaginous or resinous) that protects and lubricates meristems early in development (Fahn, 1979). The structural similarity of colleters with other types of secretory structures led researchers to confuse them with extrafloral nectaries and resin glands (Martins et al., 2010). For this reason, the term 'colleter' should be attributed only through histochemical tests that ensure the presence of mucilage in the secreted product (Martins et al., 2010; Mayer et al., 2011).

Colleters of $D$. alata have structural similarity to special glands on the floral organs of D. stipulacea (Souza et al., 2010). Nevertheless, in their investigation these structures are denominated improperly as "stalked gland" with a "head gland" and are considered to have the same functions as nectaries. However, due to the anatomy, position and other morphological similarities in the inflorescence of these two species, those glands should also be considered colleters.

The colleters of $D$. alata are classified as the standard type (Lersten, 1974). The main feature that characterize this type of colleter and distinguish them from other types are their palisade-like secretory epidermal cells that form the secretory epithelium, which delimits a central parenchymatic region. As described for the colleters of Caryocar brasiliense Camb. (Paiva and Machado, 2006), the origin of this type of colleter involves the protoderm and the ground meristem.

Vascularization was observed only in the elongated colleters of $D$. alata. The vascular tissue is formed by collateral bundles occurring in the central region of the colleters. Vascularized colleters have been reported in several species in different families such as, Rubiaceae (Klein et al., 2004) and Apocynaceae (Appezzato-da-Glória and Estelita, 2000; Martins, 2012). Nevertheless, some species exhibit only xylem, as observed in the genus Nerium L. (Thomas, 1991). According to Appezzato-da-Glória and Estelita (2000) colleters may or may not be vascularized, depending on their proximity to the vasculature of the organ to which they are attached.

In $D$. alata, the cuticle always remains intact after the secretory period of the colleters. This mechanism of liberation of the secretion without rupturing of the cuticle was also observed in Simira (Klein et al., 2004), Bathysa nicholsonii (Miguel et al., 2006) and Temnadenia violaceae (Martins et al., 2010). In contrast, Fahn (1990) assumed that the rupturing of the cuticle is a common feature in the mechanism of liberating the secretion. Nevertheless, this mechanism is scantily mentioned, being referred only to a few species of Apocynaceae (Thomas and Dave, 1989a, 1989b; Appezzato-da-Glória and Estelita, 2000).

Taking into account that the presence of colleters in Euphorbiaceae is not restricted to the genus Dalechampia, it is worth to expand investigations regarding these structures within Euphorbiaceae, as they might be useful for future phylogenetic analysis of the family.

Histochemical tests indicated that the secretion produced in the stigmatic and transmitting tissues in D. alata consists of polysaccharides, as proved by the positive reaction to PAS. The composition of the stigmatic secretion varies among species, but it consists mainly of lipids and phenolic compounds (Knox, 1984), although other components such as carbohydrates, proteins, pigments, and phenolic compounds have also been reported (Leitão and Cortelazzo, 2010).

According to Souza et al. (2010), below the epidermis of the style of D. stipulacea there is a gland that consists of radially elongated palisade cells. In this present work a similar structure was observed. The differentiation of these cells starts at the middle third of the style and near the stigma it involves all the outer circumference of the style. However, histochemical tests showed no signs 'or' types of secretory activity originating from these cells (see Table 2). The style of $D$. alata presents long strips of stigmatic tissue that extend from the gynoecial apex downwards along the stylar surface. It also presents central rifts, as described to the styles of D. stipulacea (Souza et al., 2010), both consisting of an intermediate between the commonly encountered states of hollow or solid.

Prior to anthesis cell layers of the ovary of D. alata undergo a periclinal division developing two meristems, one in the middle region of the mesophyll and the other in the inner epidermis of the floral bud ovary. This same pattern was observed in D. stipulacea (Silva and Souza, 2009; 
Souza et al., 2010) and Euphorbia species (Gagliardi et al., 2012). According to Roth (1977) the inner epidermis of the carpel is able to keep its meristematic activity for a long time resulting in a conspicuous multilayered epidermis. Besides Dalechampia and Euphorbia, this process has been reported within Euphorbiaceae in Manihot (Oliveira and Oliveira, 2009), in which it results in the formation of subadaxial and adaxial meristems that produces the mesocarp and the endocarp, respectively. Meristematic activity of the inner epidermis of the ovary is also reported in Rutaceae and Fabaceae, however, instead of two meristems as in Euphorbiaceae, they present only one, either in subepidermal layers or in the inner epidermis itself (Roth, 1977; Souza et al., 2003; Gagliardi et al., 2012).

The presence of vascular tissue in the seminal rudiment of $D$. alata confirms the statement of Tokuoka and Tobe (2003) that the ovules of the subtribe Dalechampiinae, including Dalechampia, presents a vascularized outer integument, which is unknown in the subtribes Plukenetiinae and Trigiinae.

The cells with differentiated content occurring in the chalaza were considered hypostase. According to Endress (1994), a zone with lignified cell walls (hypostase) often develops between the end of the vascular bundle and the base of the embryo sac. Although hystochemistry test were not made, these cells in D. alata are very similar to those described for D. stipulaceae (Souza et al., 2010) and other Euphorbiaceae species (Kapil and Bhatnagar, 1994). The hypostase is probably related to the translocation of nutrients into the embryo sac and endosperm (Tilton, 1980)

The projection seen at the base of the funiculus was considered as an obturator. As shown for $D$. scandens by Webster and Webster (1972), the obturator is closely apressed to the micropyle in lid-like fashion. Obturators, a transmitting plug of the placental region that facilitates entered of the polinic tube in the ovule, also occur in Liliaceae and some other groups; in Euphorbiaceae the obturator is in direct contact with the nucellus (Endress, 1994; Souza, 2009; De-Paula and Sajo, 2011). The hypothesis of nutrition is also suggested as a function of this structure (Souza, 2009). Both the presence of hypostase and the obturator were considered as an embryological characteristic of the family Euphorbiaceae by Kapil and Bhatnagar (1994).

The micropyle of $D$. alata is occluded by the nucellar beak, as reported to several other species within Euphorbiaceae (Endress, 1994; Souza et al., 2010). According to Endress (1994), both parts, the obturator and the nucellus, may proliferate to varying extents, in that either the nucellus grows out of the micropyle or the obturator grows into the micropyle.

The results obtained in the present study contributed to a better understanding of morphoanatomical and histochemical features of $D$. alata, which are involved in the adaptation to the reward system that functions to attract pollinators. In addition to histochemical analysis, we also contributed with useful taxonomical data, such as the first report of colleters in Dalechampia, the occurrence of glands, obturator, micropyle occluded by nucellar beak and meristematic activity in the ovary wall, that might be explored in future studies within the genus and other related Euphorbiaceae taxa.

\section{References}

APPEZZATO-DA-GLÓRIA, B. and ESTELITA, M.E.M., 2000. Development, structure and distribution of colleters in Mandevilla illustris and M. velutina (Apocynaceae). Revista Brasileira de Botanica. Brazilian Journal of Botany, vol. 23, no. 2, pp. 113-120. http://dx.doi.org/10.1590/S0100-84042000000200001.

ARMBRUSTER, W.S. and WEBSTER, G.L., 1981. Sistemas de polinizacão de duas espécies simpátricas de Dalechampia (Euphorbiaceae) no Amazonas, Brasil. Acta Amazonica, vol. 11, pp. 13-17.

ARMBRUSTER, W.S., 1984. The role of resin in angiosperm pollination: ecological and chemical considerations. American Journal of Botany, vol. 71, no. 8, pp. 1149-1160. http://dx.doi. org/10.2307/2443391.

ARMBRUSTER, W.S., 1996. Evolution of floral morphology and function: an integrative approach to adaptation, constraint, and compromise in Dalechampia (Euphorbiaceae). In: D.G. LLOYD and S.C.H. BARRETT, eds. Floral biology studies on floral evolution in animal-pollinated plants. New York: Chapman \& Hall, pp. 241-272.

ARMBRUSTER, W.S., LEE, J. and BALDWIND, B.G., 2009. Macroevolutionary patterns of defense and pollination in Dalechampia vines: adaptation, exaptation, and evolutionary novelty. Proceedings of the National Academy of Sciences of the United States of America, vol. 106, no. 43, pp. 18085-18090. http://dx.doi.org/10.1073/pnas.0907051106. PMid:19841278.

BARROSO, G.M., PEIXOTO, A.L., COSTA, C.G., ICHASO, C.L.F., GUIMARÃES, E.F. and LIMA, H.C., 1991. Sistemática de Angiospermas do Brasil. Viçosa: Imprensa Universitária. 326 p.

BITTRICH, V. and AMARAL, M.C.E., 1996. Flower morphology and pollination biology of some Clusia species from the Gran Sabana (Venezuela). Kew Bulletin, vol. 51, no. 4, pp. 681-694. http://dx.doi.org/10.2307/4119722.

BRUNDRETT, M.C., KENDRICK, B. and PETERSON, C.A., 1991. Efficient lipid staining in plant material with sudan red 7B or fluoral yellow 088 in Polyethylene Glycol-Glycerol. Biotechnic \& Histochemistry : Official Publication of the Biological Stain Commission, vol. 66, no. 3, pp. 111-116. http://dx.doi. org/10.3109/10520299109110562. PMid:1716161.

CAIN, A.J., 1947. The use of Nile Blue in the examination of lipids. The Quarterly Journal of Microscopical Science, vol. 88, pp. 383-392.

DAVID, R. and CARDE, J.P., 1964. Coloration différentielle des inclusions lipidique et terpeniques des pseudophylles du Pin maritime au moyen du reactif Nadi. Comptes Rendus de l'Académie des Sciences, vol. 258, pp. 1338-1340.

DAVIS, G.L., 1966. Systematic embryology of the angiosperms. New York: John Wiley \& Sons. 528 p.

DE-PAULA, O.C. and SAJO, M.G., 2011. Morphology and development of anthers and ovules in Croton and Astraea (Euphorbiaceae). Nordic Journal of Botany, vol. 29, no. 4, pp. 505-511. http://dx.doi.org/10.1111/j.1756-1051.2011.01072.x. 
ENDRESS, P.K., 1994. Diversity and evolutionary biology of tropical flowers. Cambridge: Cambridge University Press. 420 p.

FAHN, A., 1979. Secretory tissues in plants. London: Academic Press Inc. 302 p.

FAHN, A., 1990. Plant anatomy. Cambridge: Pergamon Press. 600 p.

FURR, M. and MAHLBERG, P.G., 1981. Histochemical analyses of lacticifers and glandular trichomes in Cannabis sativa. Journal of Natural Products, vol. 44, no. 2, pp. 153-159. http://dx.doi. org/10.1021/np50014a002.

GABE, M., 1968. Techniques histologiques. Paris: Masson \& Cie. 1113 p.

GAGLIARDI, K.B., ROSADO, A., SOUZA, L.A., MOSCHETA, I.S. and ALBIERO, A.L.M., 2012. Structure and development of fruits and seeds of weed species of Euphorbiaceae. Acta Botanica Brasílica, vol. 26, no. 1, pp. 38-45. http://dx.doi.org/10.1590/ S0102-33062012000100005.

GERLACH, D., 1969. Botanische Mikrotechnik: eine Einführung. Stuttgart: Georg Thieme. 311 p.

HIGH, O.B., 1984. Lipid histochemistry. New York: Oxford University Press. 68 p.

JOHANSEN, D.A., 1940. Plant microtechnique. New York: McGraw-Hill. 523 p.

JUDD, W.S., CAMPBELL, C.S., KELLOGG, E.A., STEVENS, P.F. and DONOGHUE, M.J., 2009. Sistemática vegetal: um enfoque filogenético. 3rd ed. Porto Alegre: Artmed. 714 p.

KAPIL, R.N. and BHATNAGAR, A.K., 1994. The contribution of embryology to the systematics of the Euphorbiaceae. Annals of the Missouri Botanical Garden, vol. 81, no. 2, pp. 145-155. http://dx.doi.org/10.2307/2992091.

KLEIN, D.E., GOMES, V.M., SILVA-NETO, S.J. and CUNHA, M., 2004. The structure of colleters in several species of Simira (Rubiaceae). Annals of Botany, vol. 94, no. 5, pp. 733-740. http:// dx.doi.org/10.1093/aob/mch198. PMid:15374836.

KNOX, R.B., 1984. Pollen-pistil interaction. In: H.F. LINSKENS and J. HESLOP-HARRISON, eds. Cellular interactions. Heidelberg: Springer-Verlag. $508 \mathrm{p}$.

LEITÃO, C.A.E. and CORTELAZZO, A.L., 2010. Structure and histochemistry of the stigmatic and transmitting tissues of Rodriguezia venusta (Orchidaceae) during flower development. Australian Journal of Botany, vol. 58, no. 3, pp. 233-240. http:// dx.doi.org/10.1071/BT09178.

LERSTEN, N.R., 1974. Morphology and distribution of colleters and crystals in relation to the taxonomy and bacterial leaf nodule symbiosis of Psychotria (Rubiaceae). American Journal of Botany, vol. 61, no. 9, pp. 973-981. http://dx.doi.org/10.2307/2441988.

LILLIE, R.D., 1965. Histopathologic technic and practical histochemistry. 3rd ed. New York: McGraw-Hill. 407 p.

LIU, H.F., KIRCHOFF, B.K., WU, G.J. and LIAO, J.P., 2007. Microsporogenesis and male gametogenesis in Jatropha curcas L. (Euphorbiaceae). The Journal of the Torrey Botanical Society, vol. 134, no. 3, pp. 335-343. http://dx.doi.org/10.3159/10955674(2007)134[335:MAMGIJ]2.0.CO;2.

MACE, M.E., BELL, A.A. and STIPANOVIC, R.D., 1974. Histochemistry and identification of condensed tannin precursor in roots of cotton seedlings. Phytopathology, vol. 64, pp. $1297-$ 1302. http://dx.doi.org/10.1094/Phyto-64-1297.

MARTINS, F.M., 2012. Leaf and calycine colleters in Odontadenia lutea (Apocynaceae-Apocynoideae-Odontadenieae): their structure and histochemistry. Brazilian Journal of Botany, vol. 35, no. 1, pp. 59-69. http://dx.doi.org/10.1590/S1806-99592012000100007.

MARTINS, F.M., KINOSHITA, L.S. and CASTRO, M.M., 2010. Coléteres foliares e calicinais de Temnadenia violacea (Apocynaceae, Apocynoideae): estrutura e distribuição. Brazilian Journal of Botany, vol. 33, no. 3, pp. 519-530. http://dx.doi. org/10.1590/S0100-84042010000300011.

MAYER, J.L.S., CARDOSO-GUSTAVSON, P. and APPEZZATODA-GLÓRIA, B., 2011. Colleters in monocots: new record for Orchidaceae. Flora, vol. 206, no. 3, pp. 185-190. http://dx.doi. org/10.1016/j.flora.2010.09.003.

MCMANUS, J.F.A., 1948. Histological and histochemical uses of periodic acid. Stain Technology, vol. 23, no. 3, pp. 99-108. PMid:18867618.

METCALFE, C.R. and CHALK, L., 1950. Anatomy of the dicotyledons: leaves, stem and wood in relation to taxonomy with notes on economic uses. Oxford: Clarendon Press. 724 p.

MIGUEL, E.C., GOMES, V.M., OLIVEIRA, M.A. and CUNHA, M., 2006. Colleters in Bathysa nicholsonii K. Schum. (Rubiaceae): Ultrastructure, secretion protein composition and antifungal activity. Plant Biology, vol. 8, no. 5, pp. 715-722. http://dx.doi. org/10.1055/s-2006-924174. PMid:16865660.

O'BRIEN, T.P. and MCCULLY, M.E., 1981. The study of plant structure principles and select methods. Melbourne: Termarcarphi Pty. 357 p.

OLIVEIRA, J.H.G. and OLIVEIRA, D.M.T., 2009. Morfoanatomia e ontogênese do pericarpo de Manihot caerulescens Pohl e M. tripartita Müll.Arg. (Euphorbiaceae). Brazilian Journal of Botany, vol. 32, no. 1, pp. 117-129. http://dx.doi.org/10.1590/ S0100-84042009000100012.

PAIVA, E.A. and MACHADO, S.R., 2006. Colleters in Caryocar brasiliense (Caryocaraceae) ontogenesis, ultrastructure and secretion. Brazilian Journal of Biology = Revista Brasileira de Biologia, vol. 66, no. 1B, pp. 301-308. http://dx.doi.org/10.1590/ S1519-69842006000200012. PMid:16710522.

PEARSE, A.G.E., 1985. Histochemistry: theorical and applied. Vol II. New York: Churchill Livingstone. 1055 p.

ROTH, I., 1977. Fruits of angiosperms. In: K. LINSBAUER, F.G. TISCHLER and A. PASCHER, eds. Encyclopedia of plant anatomy. Berlin: Gebruder Borntraeger. pp. 175-361.

SILVA, A.C. and SOUZA, L.A., 2009. Morphology and anatomy of the developing fruit and seed of Dalechampia stipulacea Mull. Arg. (Euphorbiaceae). Acta Scientiarum Biological Sciences, vol. 31, pp. 425-432.

SOLEREDER, H., 1908. Systematic anatomy of the dicotyledons. Oxford: Clarendon Press. $1182 \mathrm{p}$.

SOUZA, L.A., MOURÃO, K.S.M., MOSCHETA, I.S. and ROSA, S.M., 2003. Morfologia e anatomia da flor e antese de Pilocarpus pennatifolius Lem. (Rutaceae). Brazilian Journal of Botany, vol. 26, no. 2, pp. 175-184. http://dx.doi.org/10.1590/ S0100-84042003000200005.

SOUZA, L.A., 2009. Sementes e plântulas - germinação, estrutura e adaptação. Ponta Grossa: Todapalavra. 280 p. 
SOUZA, L.A., SILVA, A.C. and MOSCHETA, I.S., 2010. Morphology and anatomy of flowers of Dalechampia stipulacea Müll.arg. (Euphorbiaceae). Acta Botanica Venezuelica, vol. 33, pp. 103-117.

THOMAS, V. and DAVE, Y., 1989a. Colleters of Alstonia scholaris L. - Apocynaceae. Indian Botanical Contactor, vol. 6, pp. 25-29.

THOMAS, V. and DAVE, Y., 1989b. Histochemistry and senescence of colleters of Allamanda cathartica (Apocynaceae). Annals of Botany, vol. 64, pp. 201-203.

THOMAS, V., 1991. Structural, functional and phylogenetic aspects of the colleter. Annals of Botany, vol. 68, pp. 287-305.
TILTON, V.R., 1980. Hypostase development in Ornithogalum caudatum (Liliaceae), and notes on the other types of modifications in chalaza of Angiosperm ovules. Canadian Journal of Botany, vol. 58, no. 19, pp. 2059-2066. http://dx.doi.org/10.1139/b80-238.

TOKUOKA, T. and TOBE, H., 2003. Ovules and seeds in Acalyphoideae (Euphorbiaceae): structure and systematic implications. Journal of Plant Research, vol. 116, no. 5, pp. 355-380. http://dx.doi.org/10.1007/s10265-003-0116-4. PMid:12955569.

WEBSTER, G.L. and WEBSTER, B.D., 1972. The morphology and relationships of Dalechampia scandens (Euphorbiaceae). American Journal of Botany, vol. 59, no. 6, pp. 573-586. http:// dx.doi.org/10.2307/2441021. 